\title{
Implikasi Misiologi Dalam Pengembangan Kurikulum Agama Kristen di Gereja Lokal
}

\author{
Markus Oci 1)* \\ 1)Sekolah Tinggi Teologi Kanaan Nusantara \\ *) Email: markus.oci@gmail.com
}

Received: 04 March 2019 / Revised: 16 May 2019 / Accepted: 27 May 2019

\section{Abstrak}

Dalam kegiatan pengajaran dan pembinaan gereja, gereja harus mengejawantakan tiga tugas utama pengajaran Agama Kristen yaitu: (1) Marturia (tugas kesaksian untuk memberitakan Injil), (2). Koinonia (tugas pembinaan persekutuan), (3). Diakonia (tugas pelayanan kepada Tuhan dan sesama manusia). Gereja sebagai tempat persekutuan yang mampu mempraktekan model Eklesiologi yang dapat mempraktekan proses edukasi dengan benar dan baik. Pengembangan kurikulum gereja di lokal. Didasarkan pada kerinduan dan hasrat untuk mengembangkan kualitas anggota jemaat, oleh karena itu pengajaran kepada jemaat lokal melalui khotbah, ibadah raya, pendalaman Alkitab dan kompok sel. Pengembangan kurikulum pengajaran agama Kristen dalam gereja di lokal sangat perlu atau dibutuhkan, ada beberapa hal yang perlu diperhatikan, antara lain: Pertama, visi dan misi gereja. Visi dan misi gereja akan mewarnai kurikulum di gereja lokal. Oleh karna itu dalam tata laksana pengajaran di gereja, para pemimpin gereja atau pendeta harus mampu melahirkan berbagai topik pengajaran berdasarkan visi tersebut. Kedua, nilai-nilai yang dibangun dalam gereja, artinya merujuk kepada motto pelayanan yang dikembangkan. Dengan demikian daras pengajaran dan pembinaan di gereja lokal, harus diarahkan kepada nilai-nilai tersebut serta peruntukkan kepada pencapaian tersebut.

Kata kunci : Misiologi, Pengembangan Kurikulum, Gereja Lokal. 


\section{Abstract}

The word mission comes from the Latin word missio is the substantive form of the Mittere work order (mitto, missi, missum). In teaching and fostering church activities, it must embody the three main tasks of teaching Christianity, namely: (1) Marturia (the task of witnessing to preach the gospel), (2). Koinonia (task of fellowship coaching), (3). Diakonia (duty of service to God and fellow humans). The Church as a place of fellowship that is able to practice Ecclesiology models that can practice the education process properly and well. Development of church curricula at the local level. Based on longing and desire to develop the quality of church members, therefore teaching local congregations through sermons, religious services, Bible study and cell group. The development of a Christian religious teaching curriculum in a local church is very necessary or needed, there are several things that need to be considered, among others: First, the vision and mission of the church. The church's vision and mission will color the curriculum in the local church. Because of that, in church teaching, church leaders or pastors must be able to give birth to various teaching topics based on that vision. Second, the values built into the church, meaning referring to the service motto developed. Thus, the teaching and development program in the local church must be directed towards these values and the allocation to these achievements.

Keywords: Missionology, Curriculum Development, Local Church.

\section{Pendahuluan}

Misi adalah suatu kegiatan yang mengutus seseorang atau kelompok ke suatu tempat atau daerah tertentu, untuk melaksanakan program atau kegiatan dalam jangka waktu tertentu. Dalam konteks dan konten misi khususnya misi kedaerah-daerah tertentu, diperlukan strategi, metode dan pendekatan-pendekatan. Dalam kaitan dengan kurikulum pendidikan gereja (Pengajaran Agama Kristen Gereja Lokal) diperlukan disain kurikulum yang sesuai dengan konteks gereja lokal. Sebagai subyek pengajaran Agama Kristen, gereja harus mampu mempresentasikan pelayanan yang bersifat edukatif, inovatif dan kreaktif, oleh sebab itu gerejalah yang pertama harus mendesain program pelayanan di jemaat, keluarga, serta masyarakat. 
Gereja harus mengajarkan, mengadakan pembinaan terhadap kualitas hidup jemaat-jemaat. Gereja sebagai tempat persekutuan yang mampu mempraktekan model eklesiologi yang dapat mempraktekan proses edukasi. Salah satunya adalah harus mampu mengajarkan tentang pertumbuhan iman jemaat untuk mencapai kedewasaan iman. Sebagai tubuh Kristus, umat Allah, dan persekutuan orang percaya, dan juga institusi (lembaga) Gereja harus mampu membawa umat untuk bertumbuh dalam iman kepada Allah melalui Yesus Kristus, oleh firman-Nya. Dengan demikian Gereja terpanggil untuk melaksanakan tugas pendidikan atau pembinaan warga jemaat.

Edmund Woga, menguraikan istilah: "misiologi berasal dari kata Latin Missio adalah bentuk substantif dari kata kerja mittere (mitto, missi, missum) yang punya pengertian dasar yang beragam yaitu membuang, menembak, membenturkan, mengutus, mengirim, membiarkan, membiarkan pergi, melepaskan pergi, membiarkan mengalir" ${ }^{1}$ Dalam bahasa Latin maupun Yunani kata Misi atau Missio ini lebih cenderung berarti mengutus dan mengirim. Kata misi berasal dari kata Latin missio adalah bentuk substantive dar ikata kerja Mittere (mitto, missi, missum). Dalam konteks implikasi misiologi terhadap pengajaran dan pembinaan gereja, harus mengejawantakan tiga tugas utama pengajaran Agama Kristen yaitu: (1) Marturia (tugas kesaksian untuk memberitakan Injil), (2). Koinonia (tugas pembinaan persekutuan), (3). Diakonia (tugas pelayanan kepada Tuhan dan sesama manusia).

Dalam mendesain kurikulum Gereja atau Pengajaran Agama Kristen, harus mengejawantakan, melestarikan, ke eksistensi gereja di dunia ini. Campbell Wycoff mengemukakan ada tiga hal tugas gereja yakni: Pertama, beribadah, sebuah pelayanan yang menghubungkan komunitas orang percaya kepada Sang Pencipta, Hakim, Bapa Yang Mahakasih, Juruselamat dan sumber kekuatan serta bimbingan. Kedua, bersaksi yakni mengaktualkan pengalaman jemaat yang ditebus dan diperdamaikan kepada orang sekelilingnya supaya juga menjadi pengalaman mereka. Ketiga, berkarya dalam nama Yesus dalam rangka mengemban

${ }^{1}$ Edmund Woga. 2008. Dasar-Dasar Misiologi (Yogyakarta : Kanisius), 13. 
misi dan pelayanan Kristus dalam berbagai ragam dan situasi. ${ }^{2}$

Gereja harus mengajarkan, mengadakan pembinaan terhadap kualitas hidup jemaat-jemaat. Oleh karena itu, Gereja dalam proses edukasi, harus mengejawantakan tiga tugas utama pengajaran Agama Kristen yaitu : (1) Marturia (tugas kesaksian untuk memberitakan Injil), (2). Koinonia (tugas pembinaan persekutuan), (3). Diakonia (tugas pelayanan kepada Tuhan dan sesama manusia). Gereja sebagai tempat persekutuan yang mampu mempraktekan model eklesiologi yang dapat mempraktekan proses edukasi. Salah satunya adalah harus mampu mengajarkan tentang pertumbuhan iman jemaat untuk mencapai kedewasaan iman. Sebagai tubuh Kristus, umat Allah, dan persekutuan orang percaya, dan juga institusi (lembaga) Gereja harus mampu membawa umat untuk bertumbuh dalam iman kepada Allah melalui Yesus Kristus, oleh firman-Nya. Dengan demikian Gereja terpanggil untuk melaksanakan tugas pendidikan atau pembinaan warga jemaat.

\section{Metode Penelitian}

Penelitian ini membahas tentang Implikasi Misiologi Dalam Pengembangan Kurikulum Agama Kristen di Gereja Lokal. Penelitian ini menggunakan metode literatur. Dari hasil penelitian literatur ini penulis akan menyimpulkan Implikasi Misiologi Dalam Pengembangan Kurikulum Agama Kristen di Gereja Lokal. Implikasi Misiologi Dalam Pengembangan Kurikulum Agama Kristen di Gereja Lokal, merupakan keterampilan para Hamba Tuhan, Gembala Sidang, Penginjil dalam mendisain kurikulum Pengajaran Agama Kristen, yang disesuai dengan kondisi dan situasi jemaat yang dilayani serta memperhatikan perkembangan zaman pada masa kini.

\section{Pembahasan}

\section{Misiologi}

Kata Misiologi berasal dari kata Latin Missio adalah bentuk substantif dari kata kerja mittere (mitto, missi, missum) yang punya pengertian dasar yang

2 D. Campbell Wycoff. 1961. Theory and Design of Christian Education Curriculum (Philadelphia: The Wesmister Press), 18. 
beragam yaitu membuang, menembak, membenturkan, mengutus, mengirim, membiarkan,membiarkan pergi, melepaskan pergi, membiarkan mengalir. Dalam bahasa Latin maupun Yunani kata ini lebih cenderung berarti mengutus dan mengirim. Kata misi berasal dari kata Latin missio adalah bentuk substantive dari kata kerja Mittere (mitto, missi, missum) yang punya pengertian dasar yang beragam yaitu membuang, menembak, membenturkan, mengutus, mengirim, membiarkan, membiarkan pergi, melepaskan pergi, membiarkan mengalir. Tetapi baik dalam bahasa Latin maupun Yunani kata ini lebih cenderung berarti mengutus dan mengirim. Dalam bahasa Yunani, ada dua kata yang berkaitan dengan pengutusan (missio), yaitu 'apostello' (mengutus) dan 'pempo' (mengirim). Kata misi baru dipergunakan secara umum di dalam Gereja sejak abad ke-17. Kata yang dipakai sebelumnya adalah penyebaran iman (propagation fidei), penobatan orang-orang kafir (coversio gentil pewartaan injil ke seluruh dunia (praedicatio evangelii in universe mund), pewartaan apostolic, (Praedictatio apostoloca), usaha penyelamatan kaum barbar pracuratio salutis apus barbarous gentes), penanaman baru agama Kristen (novella christianitatis plantation) perluasan Gereja (dilatation ecclesiae).

\section{Misiologi Dalam Persektif Alkitab}

Dalam Alkitab (Perjanjian Lama mapun Perjanjian Baru) dapat dikatakan bahwa karya misi Allah sangat nyata. Edmund Woga mengatakan 'karya misi pertama-tama dilihat sebagai karya Allah, yakni Allah mengutus Diri-Nya kepada dunia'. Dalam hal ini Allah melalui CiptaanNya yaitu alam semesta dan seisinya (Kejadian 1). ${ }^{3}$ Manusia pertama Adam adalah merupakan karya CiptaanNya yang diberi mandat untuk mengelola dunia seisinya. David J. Bosach menjelaskan tentang misiologi dalam konteks Perjanjian Baru

:"Sebagai..,orang Yahudi Ia memahami diri-Nya diutus kepada bangsa-bangsaNya sendiri. Panggilan-Nya untuk bertobat berhubungan dengan orang-orang ini.. Karya hidup-Nya kepada mereka. Bahwa ia diutus hanya kepada Israel, sudah terbukti dalam Matius 1:21 dan Lukas 1:54. Menurut laporan semua Injil, pada akhirnya Ia Samaria hanya dengan rasa engan. menemukan diri-Nya

\footnotetext{
${ }^{3}$ Edmund Woga. 2002. Dasar-Dasar Misiologi (Jakarta : BPK Gunung Mulia), 57.
} 
selalu di bumu Tanah Suci. Ia muncul untuk memasuki wilayahwilayah bukan Yahudi. Dengan gelisah ia bergerak di sekitar negeri orang Yahudi, bolak balik...Justru sebagai Anak Manusia Ia harus memenuhi panggilan sebagai anak Daud: untuk membebaskan bangsa-Nya.., Ia mengabdikan diri-Nya bagi Israel dengan pengabdian tanpa syarat sementara segala permohonan lainnya (Bosch, 1959:77; diterjemahkan dari bahasa Jerman). ${ }^{4}$

Dalam uraian tersebut memberikan pemahaman bahwa Tuhan Yesus Kristus, adalah contoh nyata dari misi Allah bagi umat manusia, dimana dengan kehadiratan Tuhan Yesus Kristus memberikan harapan bagi setiap orang khususnya pada saat itu dan pada saat ini. J. Andrew Kirk mengemukan pendapatnya tentang pentingnya misi dalam konten orang percaya. "Misi adalah realita mendasar tentang kehidupan kekkristenan kita. Kita adalah orang Kristen sebab kita telah dipanggil oleh Allah untuk bekerja dengan-Nya di dalam mencapai tujuan-tujuan-Nya bagi umat manusia secara keseluruhan. Hidup kita di dunia adalah kehidupan dala misi. Hidup hanya mempunyai tujuan selama ia mempunyai dimensi misioner". 5 Jadi Misi dalam perseptif Alkitab dimulai dari Penciptaan (Kejadian 1), kemudian berlanjut sampai pada kehadiran Tuhan Yesus Kristus di dunia ini, artinya misi Allah bagi umat manusia bersifat dimanis dengan tujuan untuk memuliakan namaNya.

\section{Tujuan Misiologi Kristen}

Berdasarkan pengertian misi merupakan usaha untuk menghasilkan terobosan terhadap batas-batas antara iman kepada Yesus Kristus dan ketiadaannya. Gereja yang bermisi hadir tidak pada "ruang hampa", tetapi hadir pada suatu realitas hidup dan dalam konteks masyarakat yang majemuk. Karena itu, sebutan "Gereja Misioner" harus memperhitungkan realitas hidup dan konteks masyarakat dimana kita tinggal dan berada. Jadi sangat salah kalau pengertian misi hanya dilihat dari satu sudut pandang semata, karena betapa sering kita mendengar pengertian tentang misi yang hanya menunjuk kepada Amanat Agung, "Pergilah ke seluruh dunia", sebagai dasar kegiatan misionari. Berhubungan bagian tersebut terlalu

\footnotetext{
${ }^{4}$ David J. Bosch. 2016. Transformasi Misi Kristen. (Jakarta : BPK Gunung Mulia), 38-39.

${ }^{5}$ J. Andrew Kirk. Apa Itu MISI ?. 2018. ( Jakarta: BPK Gunung Mulia), 36.
} 
ditekankan di luar bagian-bagian Alkitab lainnya, timbul kesan bahwa perintah terakhir Yesus kepada murid-murid-Nya itu hanyalah merupakan gagasan yang mendadak, "Ah, sebelum Aku pergi, lebih baik Kukatakan kepada mereka apa yang harus dilakukan sekarang". Walaupun itu mungkin terlalu dilebih-lebihkan, nampaknya kita mempunyai kesan yang keliru tentang Misi Allah secara global untuk dunia. Oleh karena itu, kita harus memahami secara luas dan mendalam mengenai konsep teologis dan misiologis yang dijumpai dalam pengajaran Alkitab. Misalnya, fungsifungsi dasar dari pemberitaan Kristen, dialog, kesaksian, pelayanan, ibadah, pengajaran dan pemuridan. Dalam kaitan dengan Gereja Misioner tersebut, maka muncullah pertanyaan-pertanyaan seperti misalnya, bagaiamana transisi dari satu konteks budaya ke dalam konteks budaya yang lain yang mempengaruhi bentuk dan interaksi antara fungsi-fungsi dinamis ini, secara khusus dihubungkan dengan pluralitas budaya dan keagamaan yang merupakan bagian dari konteks global misi Kristen. Karena itu, menurut penulis, pengertian tentang misi sangat dipengaruhi oleh sejauh mana kita memahami konsep tentang Allah dan menafsirkan Allah dengan tepat dan benar.

\section{Pendidikan Agama Kristen}

Pendidikan Agama Kristen merupakan bagian terpenting dari pendidikan Kristen, artinya Pendidikan Agama Kristen merupakan kelanjutan dari Pendidikan Kristen, oleh sebab itu Pendidikan Kristen harus mengacu kepada proses pembelajaran secara umum dalam kekristenan sedangkan Pendidikan Agama Kristen lebih kepada pengkhususan kepada proses pembelajaran itu sendiri. Robeth R. Boehlke, mengutip asumsi John Calvin yang mengatakan memumpuk segala pengetahuan, akal dan pikiran bagi orang percaya, yakni: "PAK adalah pemumpuk akal orang-orang percaya dan anak mereka dengan Firman Allah dibawah bimbingan Roh Kudus melalui sejumlah pengalaman belajar yang dilakukan gereja, sehingga dalam diri mereka dihasilkan pertumbuhan rohani yang bersinambungan kemudian diejawantahkan semakin mendalami melalui pengabdian diri kepada Allah Bapa Tuhan Yesus Kristus berupa tindakan- 
tindakan kasih terhadap sesamanya." 6 Pendidikan Agama Kristen pada prinsipnya harus menghasilkan pertumbuhan rohani bagi setiap pribadi yang sedang belajar Agama Kristen tersebut. sementara itu E. G. Homrighausen dan I. H. Enklaar, mengatakan :

PAK mencakup segala usia, baik muda maupun muda bahkan anakanak dalam persekutuan iman yang kemudian dinyatakan dalam persekutuan bersama, sebagai berikut: Inilah arti yang sedalamdalamnya dari PAK, bahwa dengan menerima pendidikan itu, segala pelajar, muda dan tua, memasuki persekutuan iman yang hidup dengan Tuhan sendiri, dan oleh dan dalam Dia mereka terhisab pula pada persekutuan jemaatnya yang mengakui dan mempermulaikan namaNya dan segala waktu dan tempat. ${ }^{7}$

Sedangkan Markus Oci mengutip asumsi Warner C. Gradorf, menguraikan " proses pengajaran dan pembelajaran yang berdasarkan Alkitab, berpusat pada Kristus, dan bergantung pada Roh Kudus, yang membimbing setiap pribadi pada semua tingkat pertumbuhan melalui pengajaran masa kini ke arah pengenalan dan pengalaman rencana dan kehendak Allah." ${ }^{8}$ Pendidikan Agama Kristen adalah proses pembelajaran yang sengaja dan sadar di ajarkan kepada peserta didik dalam segala usia yakni : anak-anak, remaja, pemuda dan orang dewasa. Pendidikan Agama Kristen sebagai proses pendidikan yang merupakan usaha dasar oleh pengajar yang ditujukan kepada peserta didik, dalam kiatan proses pembelajaran yang berisikan ajaran-ajaran, nilai-nilai kekristenan serta penekanannya kepada ketiga aspek pendidikan yaitu: kognitif (pengetahuan), afektif (sikap), psikomotor (skill dan keterampilan), dari kesemuannya berlandaskan kepada kebenaran Firman Tuhan (Alkitabiah) atau berdasarkan kepada iman Kristen.

Subyek Pembelajaran Pendidikan Agama Kristen adalah gereja dan sekolah. Gereja adalah penanggung jawab pertama dari pelayanan, oleh sebab itu gerejalah yang pertama harus memikirkan pelayanan Pendidikan

${ }^{6}$ Robeth R. Boehlke, Sejarah Pemikiran Filsafat Pendidikan Agama Kristen (Jakarta: BPK Gunung Mulia, 2005) 413.

${ }^{7}$ E.G. Homrighausen dan I. H. Enklaar. Pembimbing Pendidikan Agama Kristen (Jakarta : BPK Gunung Mulia, 1989) 39.

${ }^{8}$ Markus Oci, 2019. Jurnal FIDEI. Pengaruh Pengelolaan Kelas Dalam Pelajaran Agama Kristen Terhadap Prestasi Siswa Belajar Di SMP Kanaan Ungaran Tahun Ajaran 2017-2018. (Tawanmangu: STT Tawangmangu), 209. 
Agama Kristen baik dalam konteks jemaat, keluarga, sekolah maupun ditengah masyarakat pada umumnya. Peran guru Pendidikan Agama Kristen atau pemimpin dalam gereja, harus mengajarkan hal-hal yang sesuai dengan ajaran gereja (dogma \& teologia) yang sesuai dengan kebenaran Firman Tuhan. Obyek Pembelajaran Pendidikan Agama Kristen adalah terdiri dari orang-orang percaya dari segala usia (dari anak-anak sampai pada lansia) dan hal ini menjadi tanggung jawab gereja, baik itu warga maupun calon warga gereja. Warga gereja yang dimaksud adalah orang Kristen yang sudah menerima Tuhan Yesus sebagai Tuhan dan Juru selamatnya. Sedangkan bagi mereka yang masih calon warga gereja adalah mereka yang terdiri dari segala usia, yang memiliki kerinduan untuk mengenal Tuhan Yesus di dalam hidupnya.

Pendidikan Agama Kristen merupakan tugas utama yang sangat penting. Hal ini menyangkut kelestarian dan kesinambungan dari eksistensi gereja didunia ini. Pendidikan Agama Kristen adalah tugas yang sangat penting bagi kelangsungan pertumbuhan jemaat-jemaat baru atau anggotaanggota baru, petobat-petobat baru baik digereja, disekolah maupun dikeluarga.

\section{Kurikulum Pendidikan Agama Kristen}

Istilah "Kurikulum" berasal dari bahasa Latin, yakni: "Curriculum" artinya jarak yang harus ditempuh oleh seseorang pelari. Dalam pengertian pembelajaran "Kurikulum" adalah jangka waktu proses pendidikan yang harus ditempuh dalam mendapatkan ijasah. S. Nasution, menguraikan pengertian Kurikulum, sebagai berikut: "Kurikulum adalah suatu yang direncanakan sebagai pegangan guna mencapai tujuan pendidikan. Apa yang direncanakan bersifat idea, suatu cita-cita tentang manusia dan warga negara yang akan dibentuk." ${ }^{9}$ Sementara itu Oemar Hamalik menjelaskan Kurikulum, sebagai berikut: "Kurikulum adalah seperangkat rencana dan pengatur mengenai isi dan bahan pelajaran serta cara yang digunakan sebagai pedoman penyelenggarakan kegiatan belajar mengajar" ${ }^{10}$ Dengan demikian kurikulum suatu rencana yang disusun untuk melancarkan proses

${ }^{9}$ S.Nasution, 2008. Asas-Asas Kurikulum. (Jakarta : Bumi Askara), 8.

${ }^{10}$ Oemar Hamalik, 2008. Kurikulum dan Pembalajaran. (Jakarta: Bumi Askara), 18. 
belajar mengajar dalam proses pendidikan atau pembelajaran, baik dalam konteks pendidikan formal, non-formal.

S. Nasution menjelaskan pengertian kurikulum lebih mendalam dan lebih luas pengertiannya, yakni: "Kurikulum dipandang sebagai suatu rencana disusun untuk melancarkan proses-belajar mengajar dibawah bimbingan dan tanggungjawab sekolah atau lembaga pendidikan berserta stap pengajarnya."11 Jadi, dapat disimpulkan bahwa "Kurikulum" adalah suatu program pendidikan yang berisikan berbagai bahan ajar dan pengalaman belajar yang diprogramkan, direncanakan dan dirancang secara sistematik atas dasar norma-norma yang berlaku, yang dijadikan pedoman dalam proses belajar-mengajar, dengan tujuan mencapai tujuan pendidikan tersebut.

Dalam Alkitab (Perjanjian Lama dan Perjanjian Baru) kurikulum adalah hal sangat penting pendidikan salah satunya didasarkan Ulangan 6:4-9. Ulangan 6:4-9 didahului dengan perintah Allah agar bangsa lsrael melakukan dan memegang teguh segala perintah dan peraturan yang Allah berikan dengan disertai janji berkat jika mereka setia melakukannya. (ayat 1-3). Tujuan perintah ini diberikan adalah supaya bangsa lsrael melakukannya ketika mereka masuk dan hidup di tanah Perjanjian. Ulangan 6;4-9 juga merupakan bagian yang sangat penting dalam kehidupan bangsa lsrael, karena berkaitan dengan perintah 'syema" yang juga harus diajarkan kepada seluruh anggota keluarga termasuk anak-anak. Robert R. Boehlke mengatakan bahwa perintah "syema" dalam Ulangan 5:4-9 merupakan suatu patokan bagi keluarga Yahudi yang harus dilaksanakan. (Syema) merupakan inti dari pengakuan iman bangsa 1srael. ${ }^{12}$ Dalam perkembangan berikutnya "syema" menjadi bagian penting bagi kehidupan bangsa lsrael dan menjadi dasar bagi pendidikan kepada anak-anak rnereka. Perintah "syema" ini berkaitan erat dengan pernyataan "pengakuan bahwa Allah itu Esa" yang merupakan kebenaran yang fundamental bagi agama lsrael dan sikap mereka kepada Allah. Yang dikaitkan dengan perintah "syema" bukan hanya mengatakan tentang "keunikan" Allah tetapi juga "kesatuan (unity)" Allah. Kudus dan menerapkan ajaran agama dalam kehidupan praktis.

\footnotetext{
${ }^{11}$ S.Nasution, 2006. Kurikulum Dan Pengajaran. (Jakarta : Bumi Askara), 5.

${ }^{12}$ Robert R. Boehlke, 2005. Sejarah Perkembangan Pikiran dan Praktek Pendidikan Agama Kristen (Jakarta: BPK Gunung Mulia) 301.
} 
Pendidikan yang diberikan Tuhan Yesus kepada para murid, yaitu: konsep berbagi hidup, Pada awalnya sebelum para murid itu benar-benar memiliki status sebagai murid Yesus, mereka terlebih dahulu menerima panggilan yang konkrit untuk menjadi "murid Tuhan", yang hidup dan berjalan bersama-sama dengan Dia. "Mari, ikutlah Aku ...". Para murid diajak untuk melihat kehidupan Yesus seutuhnya melalui pengajaranNya, bersekutu, melayani, dan menyaksikan karya kasihNya yang terbesar, yaitu kematiannya di kayu salib. Para murid secara langsung dalam pengajaran Yesus, keteladanan Yesus serta pengalaman -pengalaman. yang dialami Yesus. Kata "ikutlah Aku" menjadi sesuatu yang dinamis, dimana teori dan praktek berjalan bersamaan. inilah keefektifan darl kelompok kecil yang membawa anggota yang terlibat di dalamnya menikmati suatu kehidupan persekutuan yang wajar dan seimbang. Lois E. Lebar, mengatakan : "dalam orientasi alkitab, "kurikulum" dapat didefenisikan sebagai kegiatan-kegiatan dengan isi berotoritas yang dibimbing atau dilaksanakan oleh kepemimpinan Kristen agar dapat membawa para siswa satu langkah lebih dekat kepada kedewasaan dalam Kristus" ${ }^{13}$ Kegiatan ini melibatkan interaksi dan komunikasi antara pengajar kepada peserta didik atau jemaat sesuai dengan keberanan Firman Tuhan.

\section{Tujuan Kurikulum Pendidikan Agama}

Kurikulum dalam Pembelajaran Agama Kristen berpusat pada Alkitab Kurikulum dalam pembelajaran Pendidikan Agama Kristen adalah seluruh pengetahuan dan pengalaman yang mempengaruhi kehidupan peserta didik. Alkitab harus dihubungkan dengan kehidupan melalui pengalaman-pengalaman belajar peserta didik dan penerangan secara realitas dari kebenaran tersebut. Proses pendidikan mencakup tujuan pendidikan, kurikulum pendidikan dan metode pendidikan. Tujuan adalah suatu hasil yang diharapkan untuk dicapai. ${ }^{14}$ Tujuan pendidikan adalah pernyataan-pernyataan dari hasil yang dikehendaki untuk dicapai melalui proses pendidikan. Berbicara tentang tujuan pendidikan, baiklah disini akan dikutip dari beberapa pendapat tentang tujuan pendidikan yang dimulai dari Augustinus. Tujuan pendidikan agam Kristen adalah menghantar para

${ }^{13}$ Lois E. Lebar.2006. Education That Is Christian (Malang: Gandum Mas), 307.

${ }^{14}$ James H. Chapman,1940. "Principles of Religious Education", A Survey of Religious Education.(New York: The Ronald Press Company), p.104. 
pelajar untuk memupuk Agama Kristen kehidupan rohani, membukakan diri kepada Firman Tuhan, memperoleh pengetahuan tentang perbuatan yang dilakukan oleh Allah yang dilaporkan dalam Alkitab dan bacaan lainnya, agar dengan demikian mereka mengalami hikmat, suatu pengalaman yang di dalamnya terkandung kesalehan, persekutuan dengan Tuhan Allah, kebahagiaan pribadi, pengetahuan dan pengertian serta kemampuan untuk hidup sebagai warga gereja dalam suatu masyarakat umum. ${ }^{15}$ Erasmus yang hidup pada abad 15-16 mengetengahkan bahwa tujuan umum pendidikan bagi warga yang hidup dalam persekutuan Kristen adalah mengembangkan bakat alamiah dalam diri setiap anak didik yang belajar dalam lingkungan luas kasih yang berdisiplin agar ia mampu berpikir sedalam dan sebebas mungkin, memperoleh ketrampilan mengungkapkan pikirannya yang sejelas mungkin, baik yang lisan maupun yang tertulis serta mengamalkan gaya hidup yang sesuai dengan Injil dalam semua peranannya sebagai warga Kristen dalam masyarakat. ${ }^{16}$ Erasmus menitikberatkan bahwa yang menjadi standar nilai atas hidup anak didik (pelajar) adalah Alkitab (Injil). Tempat untuk mengamalkan hidup adalah masyarakat di mana mereka menjalankan hidupnya. Disamping diarahkan agar setiap pribadi menjadi saleh, juga diarahkan agar setiap anak didik menjadi abdi bagi masyarakatnya. Tujuan pendidikan pada umumnya adalah para pelajar yaitu anak didik baik itu laki-laki maupun perempuan dan baik anak muda maupun orang dewasa. Pendidikan diarahkan untuk pembentukan kepribadian seseorang menjadi bijaksana, saleh dan berpengertian. Kesalehan mengatur hubungan seseorang dengan Tuhan Allah dan kebijaksanaan berkenaan hubungan seseorang dengan sesama dan dunia alam. Tempat untuk mengejawantahkan kemampuan adalah masyarakat pada umumnya. Standar kehidupan yang menjadi tolah ukur adalah Alkitab.

\section{Implikasi Misiologi Dalam Pengembangan Kurikulum Pengajaran Agama Kristen di Gereja Lokal}

Salah satu tantangan yang dihadapi gereja-gereja pada zaman sekarang ini, adalah mempersiapkan kurikulum dalam jemaat lokal. Kurikulum secara sederhana dapat dimaknai sebagai rencana pembelajaran

\footnotetext{
15 Ibid., 128.

${ }^{16}$ Ibid., 292.
} 
(pengajaran) di gereja lokal. Pengajaran disampaikan melalui berbagai bentuk antara lain khotbah, seminar, pelatihan dan diskusi, dan lain-lain. Sejatinya tugas dan panggilan gereja haruslah mengajar, sebab merujuk kepada Injil Matius 28:19-20 :" Karena itu pergilah, jadikanlah semua bangsa murid-Ku dan baptislah mereka dalam nama Bapa dan Anak dan Roh Kudus, dan ajarlah mereka melakukan segala sesuatu yang telah Kuperintahkan kepadamu. Dan ketahuilah, Aku menyertai kamu senantiasa sampai kepada akhir zaman." dipahami tugas gereja yakni "mengajar segala bangsa”.

Kenneth O. Gangel mengutup pendapat Crosland, menjelaskan:

Kepemimpinan dalam gereja lokal adalah seni yang mulia untuk merencanakan bersama dan mencapai bersama sasaran yang sudah ditetapkan oleh Allah bagi manusia dalam kehidupan dan ajaranajaran Yesus Kristus. Dalam kehidupan gereja, kepemimpinan bukan sekedar metode permesinan atau metode teknik atau metode untuk memegang suatu jabatan. Padasaranya, seorang pemimpin adalah seorang yang memiliki kepribadian seperti Kristus, yang berhikmat, sifat mau berkorban, dan pekeraannya sama dengan orang lain untuk menemukan dan melakukan kehendak Allah." 17

Oleh karena itu gembala, pemimpin jemaat (pemimpin) adalah seseorang yang memelihara, membimbing umat manusia. Jerry C. Wofford, menjelaskan: "Pemimpin Kristen dengan penuh kasih sayang melayani orang lain di bawah bimbingan Bapa." ${ }^{18}$ Sedangkan Stevri Indra Lumintang mengatakan :"pemimpin kristen adalah orang pilihan, alat kepemimpinan Tuhan, memimpin karena mandat (penugasan Tuhan) berotoritas karena kebenaran Tuhan, memimpin dengan dengan kebenaran, dan tujuan untuk melaksanakan kehendak Tuhan."19 Kepemimpinan merupakan kemampuan mempengaruhi orang lain, bawahan atau kelompok, kemampuan mengarahkan tingkah laku bawahan atau kelompok, untuk mencapai tujuan

${ }^{17}$ Kenneth O. Gangel 2001. Membina Pemimpin Pendidikan Kristen (Malang : Gandum Mas ), 12.

${ }^{18}$ Jerry C.Wofford. t.th. Kepemimpinan Kristen Yang Mengubah (Yogyakarta : Yayasan ANDI, t.th) 4.

${ }^{19}$ Stevri Indra Lumintang, 2015. Theologia Kepemimpinan Kristen Theokrasi Di Tengah Sekularisasi Gerej Masa Kini. (Jakarta: Geneva Insani Indonesia, 9. 
organisasi. Kepemimpinan adalah proses mempengaruhi oleh seorang pemimpin kepada pengikutnya dalam upaya mencapai tujuan organisasi.

Kepemimpinan sangat baik apabila digunakan di dalam memimpin sebuah lembaga atau organisasi pada umumnya. Kharisma seorang pemimpin dalam mempengaruhi bawahannya sangat kuat. Para bawahan menjadi sangat giat dalam menyelesaikan sebuah misi setelah menerima pengaruh dari pemimpinnya yang kharismatik. Hal-hal yang mempengaruhi proses pengaruh kharismatik seorang pemimpin adalah personal karakter, yaitu karakter dasar dari seorang pemimpin yang sangat menentukan apakah ia memiliki kharisma atau tidak terhadap bawahannya, seorang pemimpin yang menjadi sumber pembelajaran dan inspirasi bagi orangorang di sekitarnya. Kepemimpinan transformasional dapat diartikan sebagai proses untuk mengubah dan mentransformasikan individu agar mau berubah dan meningkatkan dirinya, yang didalamnya melibatkan motif dan pemenuhan kebutuhan serta penghargaan terhadap para bawahan. Berkaitan dengan hal ini, gereja harus berkembang dalam visi dan misi yang telah ditetapkannya. Secara singkat disebut bahwa visi (vision: melihat, memandang) hal-hal yang akan dicapai oleh gereja atau tujuan dari gereja, sedangkan misi (mission : cara langkah, action) yang diperlukan oleh gereja dalam mencapai tujuan dari gereja itu sendiri. Antara visi dan misi keduanya saling berkaitan dan tidak dapat dipisahkan. Dalam proses kepemimpinan gereja, seluruh kegiatan dan perjalanan pelayanan gereja mengacu pada visi dan misi yang telah ditetapkan oleh gereja tersebut. Bukan saja hanya dala program pelayanan gerejawi, akan tetapi tata kerja (managemen) gereja juga diatur berdasarkan pada visi dan misi tersebut. Visi utama gereja adalah menghadirkan syalom Allah di tengahtengah dunia semi terciptanya keadilan, perdamaian, dan keutuhan ciptaan. Perlu disadari bahwa dalam tiap langkah-langkah yang dibuat dan diambil oleh gereja sebagai bentuk kebajikan terhadap gereja yang tidak selamanya berjalan mulus sesuai dengan apa yang telah direncanakan. Akan dijumpai berbagai goncangan, tantangan, bahkan perselisihan yang mungkin akan berjuang pada sebuah perpecahan dalam tubuh gereja. Dalam tubuh organisasi kegerajaan hal itu telah terjadi beberapa kali perpecahan yang melahirkan organisasi kegerejaan yang baru. 


\section{Kurikulum di Gereja Lokal}

Dalam hal tugas gereja mengajar maka hal yang sangat prinsip dan hakiki dipegang ialah bagaimana kurikulum pengajaran yang diberikan kepada jemaat mampu menolong jemaat-jemaat bertumbuh dan dewasa secara berkelanjutan. Untuk hal ini salah satu pembenahan yang harus dilakukan ialah "kurikulum gereja" harus mumpuni dan memberikan jawaban atas pergumulan dari jemaat-jemaat yang dilayani, selain dari tuntutan perkembangan zaman. Tujuan disain kurikulum di gereja lokal tersebut ialah untuk meningkatkan kualitas dan layanan pendidikan baik yang menyangkut pada aspek input, proses dan output. Hal serupa juga hendaknya menjadi landasan dan dasar bagi penyusunan serta pengembangan kurikulum gereja lokal. Pada prinsipnya didasarkan pada kerinduan dan hasrat untuk mengembangkan kualitas jemaat-jemaat, maka pengajaran dan kurikulum pelajaran di gereja lokalyang diajarkan (khotbah, ibadah raya, komsel dan pengajaran-pengajaran) seharusnya mendapat tanggapan untuk perubahan. Dengan demikian akan terjadi perbaikan yang secara terus menerus dalam layanan "kualitas" pengajaran gereja.

Dalam rangka mewujudkan pengembangan kurikulum dalam gereja lokal, maka ada beberapa hal yang perlu diperhatikan, antara lain: Pertama, perhatikanlah visi dan misi gereja. Visi dan misi gereja akan mewarnai kurikulum gereja. Misalnya saja jika visis gereja:"Menjadi Seperti Yesus", maka dalam tata laksana pengajaran di gereja, para pemimpin gereja atau pendeta harus mampu melahirkan berbagai topik pengajaran berdasarkan visi tersebut. Tugas para gembala mendesain visi tersebut kemudian dilaksanakan, maka sesuai dengan jangka waktu itulah kurikulum pengajaran dibentuk. Kedua, perhatikan nilai-nilai atau asas-asas yang dibangun dalam gereja, biasanya hal ini merujuk kepada motto pelayanan gereja tersebut yang dikembangkan. Maka seharusnya dasar pengajaran dan pembinaan di gereja, dan harus diarahkan kepada nilai-nilai tersebut, juga diarahkan kepada pencapaianya. Ketiga, menyusun kurikulum berdasarkan statu atau anggaran dasar dan anggaran rumah tangga gereja tersebut. Hal ini tidak bisa terlepas dari tata gereja secara sinode. Keempat, menyusun kurikulum berdasarkan doktrin gereja, berdasarkan doktrin gereja maka kita akan lebih mudah memahami sampai dimana ajaran-ajaran yang akan kita sampaikan kepada jemaat.Biasanya pokok pengajaran yang berupa doktrin menjadi patokan dan juga norma pengembangan kurikulum di gereja lokal. 
Dalam hal penyusunan kurikulum di gereja lokal, sebaiknya memperhatikan kategori baik jangka pendek, menengah dan panjang. Pengajaran dalam jangka pendek, dimulai dengan hal-hal yang praktis, dimana para pendeta atau gembala bisa mengkhotbahkannya serta mengajarkannya dalam kurun waktu yang relatif singkat. Untuk kurikulum jangka menengah hal ini harus dilakukan berdasarkan kebutuhan lanjutan dari jangka pendek, hal ini berarti diperlukan karna dalam konteks dan konten kurikulum jangka pendek tidak mampu menampung dan menyelesaikannya, karena itu dibutuhkan lanjutan pengajaran atau khotbah yang serial.

\section{Kurikulum Khotbah}

Mengajar hanya dapat dilakukan dengan baik jika dalam sebuah gereja ditemukan kelengakapan yang memadai, salah satu diantaranya ialah kurikulum (rencana pelajaran). Michael Stephen Schiro, menjelaskan tentang kurikulum tergprogram "kurikulum terprogram yang terdiri atas kumpulan pengalaman belajar yang diurutkan dengan seksama, yang masingmasing mewakili yang akan dipelajri" ${ }^{20}$ Artinya rencana disain pengajaran harus dipersiapkan sistematis dan terencana. Hal ini para pendeta, gembala sidang dan penginjil dapat mendesaindengan sebaiknya. Tugas dan tanggungjawabpendeta, gembala sidang dan penginjil adalah mendesain kurikulum pengajaran Agama kristen di gereja lokal, dapat diejawantakan dalam bentuk kurikulum khotbah (pengajaran). kurikulum khotbah bisa berupa modul pengajaran yang dibuatkan berdasarkan klasifikasi di atas, hasil ini akan memudahkan bagi para pendeta, gembala sidang dan penginjil yang akan menggunakan kurikulum tersebut dalam pengajarannya (khotbah).

Modul yang dibuatkan bisa berdasarkan tematik sesuai dengan rencana khotbah atau pengajaran mimbar, namun dapat juga berdasarkan sajian yang mengikuti waktu dan kalender pelayanan gerejawi. Keuntungan gereja memiliki kurikulum di jemaat lokal, gereja akan tertata secara baik dan sistematik dalam hal pengajaran, lebih lanjut dengan hal ini akan lebih mudah dilakukan evaluasi tentang pemahaman dan pengetahuan jemaat terhadap ajaran-ajaran di gereja tersebut. Bagi para hamba Tuhan, dengan

${ }^{20}$ Michael Stephen Schiro, 2017. Teori Kurikulum (Jakarta : Indeks), 83. 
adanya kurikulum di jemaat lokal adalah lebih mudah melaksanakan khotbah-khotbah dan pengajaran, baik yang sifatnya umum maupun klasikal. Harapannya bahwa para pendeta akan mampu memberikan pengajaran yang sistematis dan menyentuh kebutuhan jemaat; sehingga jemaat-jemaat bertumbuh dengan baik.

\section{Disain Kurikulum Gereja di Era Globalisasi}

Kemajuan zaman menuntut gereja-gereja untuk mengupgrade diri dalam hal kurikulum pengajaran. Era dimana kita disebut dengan era globalisasi yang ditandai dengan kemajuan cepat serta mendunia di bidang informasi dan teknologi dalam dua dasawasa terakhir telah berpengaruh pada peradaban manusia melebihi jangkauan pemikiran sebelumnya. Pengaruh ini terlihat pada pergeseran tatanan sosial, ekonomi dan politik bahkan juga dalam bidang keagamaan atau religious. Tantangan zaman ini memerlukan kesiapan gereja-gereja untuk menyelenggarakan pendidikan warga jemaat melaui mimbar dengan sajian pengajaran yang terinci, tersistem dan juga terencana. Pada hakekatnya kurikulum pengajaran di gereja, akan memberikan dampak yang positif dan baik jika, didesain sesuai dengan kebutuhan jemaat. Gereja harus mengimbangi perkembangan zaman dan teknologi, dimana setiap saat menyuguhkan perubahan-perubahan yang sangat cepat. Oleh sebab itu menjadi landasan dan dasar bagi penyusunan serta pengembangan kurikulum gereja lokal di era modern. Hal ini didasarkan pada kerinduan dan hasrat untuk mengembangkan kualitas jemaat-jemaat, maka pengajaran dan kurikulum pelajaran jemaat (baik melalui Khotbah, Ibadah Raya, Pendalaman Alkitab, Komsel) seharusnya mendapat tanggapan untuk perubahan.

\section{Kesimpulan}

Untuk mewujudkan implikasi misiologi dalam pengembangan kurikulum digereja lokal, maka ada beberapa hal yang perlu diperhatikan, antara lain: Pertama, perhatikanlah visi dan misi gereja. Visi dan misi gereja akan mewarnai kurikulum gereja. Misalnya saja jika visi gereja :'Menjadi Seperti Yesus", maka dalam tata laksana pengajaran di gereja, para pemimpin gereja atau pendeta harus mampu melahirkan berbagai topik pengajaran berdasarkan visi tersebut. Belum lagi tugas para gembala untuk mendesain berapa lama visi tersebut akan digarap, maka sesuai dengan 
jangka waktu itulah kurikulum pengajaran dibentuk. Kedua, nilai-nilai yang dibangun dalam gereja, biasanya hal ini merujuk kepada motto pelayanan yang dikembangkan. Kategori pengembangan kurikulum di gereja lokal, yakni: jangka pendek-menengah-panjang. Nilai-nilai yang dibangun dalam gereja, harus terealisasi melalui bahan pengajaran yang bentuk dan modelnya disesuaikan dengan kebutuhan jemaat lokal. Ketiga, statau atau anggaran dasar dan anggaran rumah tangga gereja tersebut. Hal ini tidak bisa terlepas dari tata gereja secara sinodal. Berdasarkan hal ini maka kita akan mampu membentuk kurikulum yang komprehensif dan mumpuni dalam mengembangkan gereja lokal. Keempat, doktrin gereja, berdasarkan doktrin gereja secara secara sinode akan lebih mudah memahami sampai dimana ajaran-ajaran yang akan dijarkan sampaikan kepada jemaat. Biasanya pokok pengajaran yang berupa doktrin ini menjadi patokan dan juga norma pengembangan kurikulum di gereja lokal.

\section{Kepustakaan}

Alkitab, 2010. Lembaga Alkitab Indonesia. Jakarta : LAI.

Anthony. Michaeal J (Ed). 2012. Foundations Of Ministry An Introduction

To Christian Education For A New Generation. Malang: Gandum Mas.

Bosch, David J. 2016. Transformasi Misi Kristen. Jakarta : BPK Gunung Mulia.

Boehlke, Robert R. 2005. Sejarah Perkembangan Pikiran dan Praktek Pendidikan Agama Kristen. Jakarta: BPK Gunung Mulia.

Campbell, D. Wycoff. 1961. Theory and Design of Christian Education Curriculum. Philadelphia: The Wesmister Press.

Chapman, James H. 1940. Principles of Religious Education, A Survey of Religious Education. New York: The Ronald Press Company.

Chroom, Thomas. 2010. Religious Education. Terjemahan, Jakarta : BPK Gunung Mulia.

Gangel, Kenneth O. 2001. Membina Pemimpin Pendidikan Kristen. Malang: Gandum Mas.

Geister, Norman L \& Feinberg. 2002. Filsafat Dalam Persepktif Kristiani. Malang: Gandum Mas.

Hamalik, Oemar. 2008. Kurikulum dan Pembelajaran. Jakarta: Bumi Askara. 
James H. Chapman, 1940. Principles of Religious Education, A Survey of Religious Education. New York: The Ronald Press Company.

Kuiper, Arie De. 2015. Misiologi. Jakarta: BPK Gunung Mulia.

Krik, J. Andrew. 2018. APA ITU MISI? Suatu Penelusuran Teologis. Jakarta: BPK Gunung Mulia.

Lumintang, Stevri Indra. 2015. Theologia Kepemimpinan Kristen Theokrasi Di Tengah Sekularisasi Gereja Masa Kini. Jakarta: Geneva Insani Indonesia.

Loia E, Lebar, 2006. Education That Is Christian. Malang: Gandum Mas.

S. Nasution, 2008. Asas-Asas Kurikulum. Jakarta: Bumi Askara. , 2006. Kurikulum Dan Pengajaran. Jakarta: Bumi Askara.

Schiro, Michael Stephen, 2017. Teori Kurikulum. Jakarta: Indeks.

Oci, Markus, 2019. Jurnal FIDEI. Pengaruh Pengelolaan Kelas Dalam Pelajaran Agama Kristen Terhadap Prestasi Siswa Belajar Di SMP Kanaan Ungaran Tahun Ajaran 2017-2018. (Tawanmangu: STT Tawangmangu), 209.

Woga, Edmud. 2008. Dasar-Dasar Misiologi. Yogyakarta: Kanisius.

Wofford, Jerry C. t.th. Kepemimpinan Kristen Yang Mengubah. Yogyakarta: Yayasan ANDI. 